DOI: $10.20472 / B M C .2018 .008 .009$

\author{
HELENEZE LUES \\ North-West University, South Africa
}

MARKO VAN DEVENTER

North-West University, South Africa

\title{
EXPLORING THE FACTORS THAT INFLUENCE GENERATION Y STUDENTS' ATTITUDES TOWARDS UNIVERSITY WEBSITES
}

\begin{abstract}
:
In South Africa, an increasing number of Generation $Y$ students register at higher education institutions on an annual basis. This rising number, coupled with university websites being a primary source of information and a basis for creating institutional impressions that can affect the attitudes and behavioural intentions of students, highlights the importance of understanding the factors that influence Generation Y students' attitudes towards university websites. As such, the purpose of this study was to determine the influence of ease of use, usefulness and playfulness on Generation $Y$ students' attitudes towards university websites within the South African context. A self-administered questionnaire was used to collect data from a convenience sample of 319 Generation $Y$ students registered at two higher education institution campuses in the Gauteng Province of South Africa. Data analysis included descriptive statistics, correlation analysis and multivariate regression analysis. The findings indicate that the ease of use, usefulness and playfulness of university websites have a significant positive influence on Generation $Y$ students' attitudes towards university websites. Universities can use the findings of this study to improve the effectiveness of their websites in an attempt to positively influence Generation $Y$ students' attitudes towards the sites.
\end{abstract}

\section{Keywords:}

Generation Y students; attitudes; university websites; multivariate regression analysis; South Africa

JEL Classification: M31, M30, M37 


\section{INTRODUCTION}

Prior to the advent of the internet in the 1970s, business overviews and information wereinaccessible to the vast majority of the population (Schneider \& Perry, 2000). However, advancement in technology from a static World Wide Web to the Web 2.0 brought about the facilitation of an ever-increasing level of interactivity, collaboration and content sharing between businesses and the public (Allen, 2012). Marketers of the $21^{\text {st }}$ century therefore recognise the importance of an effective website, not only as a key component to business survival in the ever-globalising competitive online environment(Mentes \& Turan, 2012), but also asa way of reaching intended target audiences, improving the operational efficiency and image of the business, as well as to tap into global markets (Ganiyu, Mishra, Elijah \& Gana, 2017; Mentes \& Turan, 2012). University websites are no different in this regard.

A university website is one of the primary resourcesthat current and prospective students use to learn about a university (Carnevale, 2005), and remain the most prevalent outlet for most student inquiries (Saichaie \& Morphew, 2014). These sites are also a cost effective and timely method to communicate with a number of stakeholders, including both current and prospective students, faculty and administrative staff as well as other visitors (Mentes \& Turan, 2012). Given that university websites are a primary source of information and because the images and text displayed on these sites provide many students with their first and only institutional impressions of the university, it is important that universities should invest considerable time and effort in the messages it is attempting to convey. Moreover, taking into account the expense to develop and maintain a website, as well as the high profile associated with institutional websites, universities are compelled to strategically and purposefully communicate well-crafted messages (Schneider \& Bruton, 2004). While students use university websites to differentiate between the different universities in the marketplace, universities deploy websites to communicate distinctive and mission-specific qualities (Anctil, 2008). As such, a university websiteis an essential tool to universities' marketing practices (Carnevale, 2005).To ensure that a university's website contributes to the successful marketing of the university, it is important that marketing practitionersshould understand the behavioural aspect of consumer attitudes and the factors that influence attitudes towards university websites among users, in general, and the Generation $\mathrm{Y}$ cohort, in particular.

In consumer behaviour literature, attitude is described as a learned tendency to behave either consistently positively or negatively towards a specific object (Joubert, Erdis, Brijball Parumasur \& Cant, 2013). An individual's attitude develops through life experiences (Himansu, 2009), and although attitude is enduring (Schiffman, Kanuk \& Wisenblit, 2010), certain external factors may affect and shift an individual's attitude (Hanna \& Wozniak, 2001). Attitude fulfils a personal motive, while simultaneously influencing an individual's behaviour (Dean, 2010). An individual whodisplays a positive 
attitude towards a specific behaviour will in all likelihood engage in that behaviour (Schiffman et al., 2010). Attitude towards a website is a "predisposition to respond favourably or unfavourably to web content in natural exposure situations" (Chen \& Wells, 1999:28). As such, a positive attitude towards university websites may elicit proactive engagement with the sites. Previously published studies confirm the positive relationship between attitude and the behavioural intention to use a website (Ahn, Ryu \& Han, 2007; Seock \& Norton, 2007; Van der Heijden, 2003).

The youth market segment, commonly referred to as Generation $Y$ (Markert, 2004) or the Internet Generation (Severt, Fjelstul \& Breiter, 2013), consists of individuals born between 1986 and 2005 (Markert, 2004). This generation has grown up in the digital age, has a tendency of being technologically astute, and are heavy users of digital platforms (Nadeem, Andreini, Salo \& Laukkanen, 2015) and the internet (Bilgihan, 2016). It therefore comes as no surprise that this digitally connected generation regularly browses the internet to source information when making important decisions (Valentine \& Powers, 2013), including their university of choice. In South Africa, an increasing number of Generation $Y$ students register at higher education institutions on an annual basis(Department of Higher Education and Training, 2017). Given this rising number and the fact that university websites serve as an important source of information, it is surprising that there is a dearth of published studies on university websites within the South African context. Even more worryingly, Generation $Y$ students' attitudes towards university websites seem to have been largely under-researched.

\section{PURPOSE OF THE STUDY AND RESEARCH QUESTIONS}

To address the gap in the literature, the purpose of this study was to determine the influence of selected factors, namely usefulness, ease of use and playfulness, on Generation $Y$ students'attitudes towards university websites within the South African context.The research questions addressed in this study are as follows:

- Is perceived usefulness a positive predictor of Generation $Y$ students' attitudes towards university websites?

- Is perceived ease of use a positive predictor of Generation Y students' attitudes towards university websites?

- Is perceived playfulness a positive predictor of Generation $Y$ students' attitudes towards university websites?

\section{LITERATURE REVIEW}

\subsection{Perceived usefulness}

Perceived usefulness is explained as "the degree to which a person believes that using a particular system would enhance his or her job performance" (Chung \& Tan, 2004:870; Van der Heijden, 2003:542). Perceived usefulness is also described as a user's rational 
reaction to the use of a website (Gefen, 2003), and therefore could be viewed as a rational factor (Liao, To, Liu, Kuo \& Chuang, 2011). Within a university website context, perceived usefulness is described as the degree to which an individual believes that using a university website can effectively fulfil his or her personal requirements for information seeking. Users whobelieve that the website is useful in satisfying their personal needs are more likely to display a positive attitude towards the website. Indeed, the relationship between usefulness and attitudes towards websites has been validated in several international studies. For example, in their study, Ahn et al. (2007) found that usefulness has a direct positive influence on attitudes towards an online retail website. Similarly, Van der Heijden (2003) reported that usefulness is a significant positive predictor of attitudes towards a Dutch generic portal site. In line with the results of these studies, this study proposes the following hypothesis:

H1: Usefulness positively influences Generation $Y$ students' attitudes towards university websites.

\subsection{Perceived ease of use}

In general terms, perceived ease of use refers to the degree to which the user of a website understands the structure of a website, its interface, functions and the content (Casalo, Flavian \& Guinaliu, 2008). In addition, ease of use denotes the speed at which users find the relevant information, ease of site navigation and the user's ability to control what he or she is doing, and where they are, at any given time (Flavian, Guinaliu \& Gurrea, 2006).In essence, ease of use impliesproviding users with systems, including university websites that require minimal mental and physical effort to achieve the desired outcomes (Davis, 1989; Sindhuja \&Dastidar, 2009). Therefore, if users believe that a university website is free of any effort, straightforward and simple to use, then they are most likely to display a favourable attitude towards the website. A number of studies have confirmed the association between ease of use and attitudes towards websites. Hung, Tsai and Chou (2016) discovered that ease of use has a direct positive influence on attitudes towards two social networking websites, namely Facebook and professional technology temple, which is the largest bulletin board system in Taiwan with more than one million registered users. The Ahn et al. (2007) study also found that ease of use has a direct positive influence on attitudes towards an online retail website. In accordance with the findings of these studies, the following hypothesis was developed:

H2: Ease of use positively influences Generation $Y$ students' attitudes towards university websites.

\subsection{Perceived playfulness}

Perceived playfulness is defined in terms of three dimensions, namely concentration, which is the extent to which the user believes that his or her attention is focused on the stimulus (website);curiosity, which is the extent to which the useris inquisitive about the 
interaction; and lastly, enjoyment, which is the degree to which the interaction is interesting and fun (Moon \& Kim, 2001). Moreover, playfulness is considered an intrinsic motive or belief, which is shaped from the user's experiences with the environment (Moon \& Kim, 2001). Playfulness is therefore an intensely irrational, spontaneous and personal activity (Serenko \& Turel, 2007). From a website perspective, playfulness is an intrinsic motive that is formed from the user's subjective experience with the website (Liao et al., 2011). Those users with a positive playfulness belief in the website should have positive interactions with the website, and consequently display a positive attitude towards the website.Playfulness has been found to have a direct positive influence on users' attitudes towards the World Wide Web (Moon \& Kim, 2001), a virtual store in Korea (Oh, Kim, Lee, Shim, Park \& Jung, 2009) and virtual reality applications based on a web camera inputinterface (Sun \& Cheng, 2009). Based on the results of these studies, the hypothesis for this study was developed as follows:

H3: Playfulness positively influences Generation Y students' attitudes towards university websites.

\section{RESEARCH MODEL}

Previous theoretical and empirical studies highlight the significance of attitudes towards websites. The suggested research model, as depicted in Figure 1, determines the influences of perceived usefulness, ease of use, and playfulness on Generation $Y$ students' attitudes towards university websites. In accordance with the literature, usefulness, ease of use and playfulness are presumed to have a direct positive influence on Generation Y students' attitudes towards university websites.

\section{Figure 1: Research model}

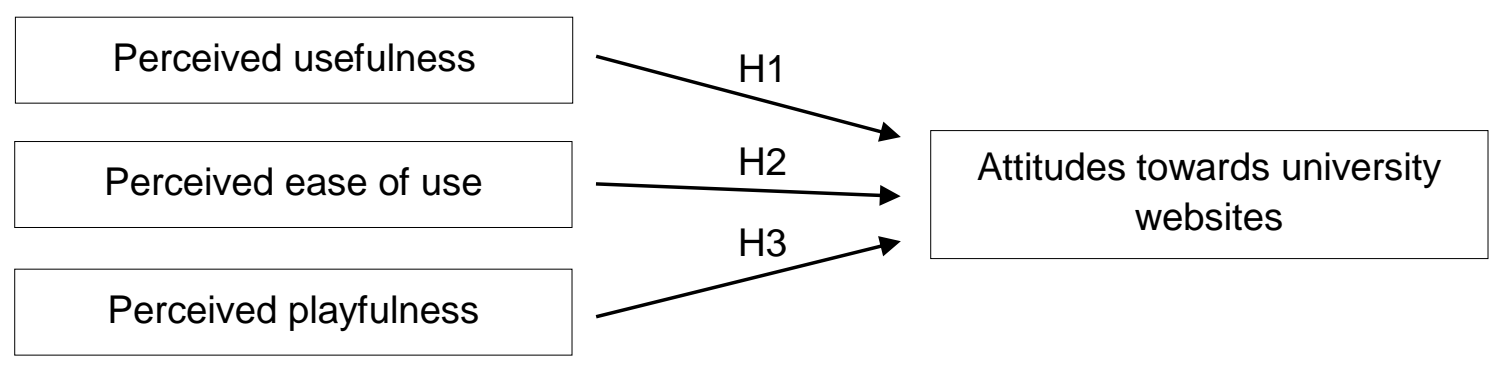

Source:Own research

\section{METHODOLOGY}

\subsection{Research design and approach}

A descriptive, single cross-sectional research design was followed in this study.

\subsection{Sample}

The target population for this study was outlined as Generation $Y$ students between the ages of 18 and 24 years, who were enrolled at South African public higher education 
institutions (HEls). The sampling frame included the 26 South African public HEls. By means of judgement sampling, two HEI campuses based in Gauteng were selected from the sampling frame. Subsequently, a non-probability convenience sample of 400 students was taken, which was evenly split between the two campuses, leaving a sample of a 200 students per campus.

\subsection{Measurement instrument and data collection procedure}

A self-administered questionnaire was used to collect the required data for the study. The first section of the questionnaire requested the participants' demographic information. In addition, a cover letter was included to explain the purpose of the study and highlighted that the participants' information will only be outlined in the form of statistical data. The second section of the questionnaire included questions pertaining to the four constructs of the study, namely ease of use, usefulness, playfulness and attitudes. Ease of use was measured using three items (Flavián et al., 2006; Van der Heijden, 2003), usefulness using five items (Ahn et al., 2007; Flavián et al., 2006; Sindhuja \& Dastidar, 2009; Van der Heijden, 2003), playfulness using five items (Ahn et al., 2007; Liu \& Arnett, 2000; Van der Heijden, 2003) and attitudes towards university websites using three items (Ahn et al., 2007; Van der Heijden, 2003). The participants' responses were measured on a sixpoint Likert-type scale that ranged from strongly disagree (1) to strongly agree (6).

Prior to data collection, an application for ethical clearance was submitted to the Social and Technological Sciences Research Ethics Committee of the Faculty of Economic Sciences and Information Technology at the North-West University. After receiving ethical clearance, permission to distribute the questionnaire was requested from the two HEI campuses. Once permission was granted, student fieldworkers distributed the questionnaires for voluntary completion by making use of the mall-intercept survey method.

\subsection{Data analysis}

The IBM Statistical Package for Social Sciences (SPSS), version 25 was used to perform the data analyses. The statistical methods used to analyse the data were descriptive statistics, reliability statistics, Pearson's product-moment correlation analysis, collinearity diagnostics and multivariate regression analysis.

\section{RESULTS}

From the 400 questionnaires that were distributed, 319 were complete and usable for further analysis, giving this study a response rate of nearly 80 percent. The sample included more female students than male students. In terms of age, the majority of the participants were 20 years of age, followed by those who were 18 and 19 years of age. Furthermore, the largest portion of the sample wasfirst-year students, followed by those who were in their third year of study. The demographic information of the sample is provided in Table 1. 
Table 1: Sample description

\begin{tabular}{lclccc}
\hline Gender & Percent (\%) & Age & Percent (\%) & Year of study & Percent (\%) \\
\hline Female & 51.4 & $<18$ & 0.9 & $1^{\text {st }}$ year & 50.2 \\
Male & 18 & 19.4 & $2^{\text {nd }}$ year & 11.0 \\
& 48.6 & 17.2 & $3^{\text {rd }}$ year & 26.8 \\
& 20 & 24.1 & $4^{\text {th }}$ year & 10.7 \\
& 21 & 16.0 & Post-graduate & 1.3 \\
& 22 & 11.3 & & \\
& 23 & 6.6 & & \\
& 24 & 4.1 & & \\
& 25 & 0 & & \\
& 25 & 0.3 & & \\
& & &
\end{tabular}

Source:SPSS output (2018)

The Cronbach alpha values for each construct werecomputed to evaluate the internal consistency reliability of the measurement instrument. The Cronbach alpha values of the individual constructs ranged between 0.745 and 0.837 . These values are above the recommended level of 0.70 (Field, 2009), thereby suggesting acceptable internal consistency reliability.

The descriptive statistics for each construct as well as Pearson's product-moment correlation coefficients for each pair of constructs were computed. Correlation analysis was done to determine the relationship between ease of use, usefulness, playfulness and attitudes, and to assess whether there were any multicollinearity concerns. The means, standard deviations and correlation coefficients are presented in Table 2.

Table 2: Descriptive statistics and correlation coefficients

\begin{tabular}{lccccc}
\hline Constructs & Mean & Standard deviation & Ease of use & Usefulness & Playfulness \\
\hline Ease of use & 4.27 & 1.09 & & & \\
Usefulness & 4.25 & 0.91 & $0.624^{* *}$ & & \\
Playfulness & 3.51 & 1.12 & $0.496^{* *}$ & $0.601^{* *}$ & \\
Attitudes & 4.27 & 1.14 & $0.534^{* *}$ & $0.685^{* *}$ & $0.648^{* *}$ \\
\hline${ }^{* *}$ Statistically significant at $p \leq 0.01$ (2-tailed) & & & \\
\hline
\end{tabular}

Source:SPSS output

As delineated in Table 2, the means for the four constructs were above 3.5, which, given thesix-point Likert-type scale used, indicates that Generation $Y$ students perceive their university website as being user-friendly, entertaining, enjoyableand effective in stimulating curiosity and providing interesting and relevant information. Furthermore, the sample seems to display a positive attitude towards their university website. With regard to the correlation analysis, statistically significant positive relationships were found between each of the constructs, ranging between $(r=0.496 ; p<0.01)$ and $(r=0.685$; 
$\mathrm{p}<0.01$ ), suggesting nomological validity (Hair et al., 2010). In addition, none of the correlation coefficients exceeded the 0.80 level, and therefore no obvious multicollinearity issues exist (Field, 2009).

Following the correlation analysis, multivariate regression analysis was performed to determine the influence of ease of use, usefulness and playfulness on Generation $Y$ students' attitude towards their university website. Table 3 reports on the regression model summary and ANOVA results.

Table 3: Regression model summary and ANOVA results

\begin{tabular}{cccccc}
\hline & $\mathbf{R}$ & $\mathbf{R}^{\mathbf{2}}$ & Adjusted $\mathbf{R}^{2}$ & $\mathbf{F}$ & p-value \\
\hline Model 1 & 0.751 & 0.564 & 0.559 & 135.573 & $\mathbf{0 . 0 0 0}$ \\
\hline
\end{tabular}

Source:SPSS output

The significant F-ratio $(p \leq 0.01)$ in Table 3 suggests that Regression Model 1 predicts Generation $Y$ students' attitude towards their university website. The $R^{2}$ value indicates that close to 57 percent of the variance in Generation $Y$ students' attitude towards their university website is explained by the three independent variables. However, since 43 percent of the variation in Model 1 is not explained by these dimensions, it is reasonable to assert that other factors also influence Generation $Y$ students' attitudes towards their university website.

Subsequent to performing the regression analysis, the next step was to determine the extent to whicheach construct contributes towards the prediction of attitudes towards university websites. These statisticsareoutlined in Table 4.

Table 4: Contribution of independent variables to predict students' attitudes towards university websites

\begin{tabular}{lccccc}
\hline $\begin{array}{l}\text { Independent } \\
\text { variables }\end{array}$ & $\begin{array}{c}\text { Standardised } \\
\text { beta coefficient }\end{array}$ & t-values & p-values & \multicolumn{2}{c}{ Collinearity statistics } \\
\cline { 5 - 6 } & 0.105 & 2.168 & $\mathbf{0 . 0 3 1}$ & 0.588 & Volerance \\
Ease of use & 0.409 & 7.751 & $\mathbf{0 . 0 0 0}$ & 0.498 & 2.702 \\
Usefulness & 0.350 & 7.383 & $\mathbf{0 . 0 0 0}$ & 0.615 & 1.626 \\
\hline
\end{tabular}

Source:SPSS output

Table 4 and Figure 2 indicate that ease of use $(\beta=0.105,0.031<0.05)$, usefulness $(\beta=$ $0.409,0.000<0.05)$ and playfulness $(\beta=0.350,0.000<0.05)$ have a statistically significant positive influence on Generation $Y$ students' attitudes towards their university website. The largest beta coefficient was recorded on usefulness, which means that usefulness makes the strongest contribution to explain Generation $Y$ students' attitude towards their university website. These findings are consistent with similar studies that also found that ease of use (Ahn et al., 2007; Hung et al., 2016), usefulness (Ahn et al., 
2007; Van der Heijden, 2003) and playfulness (Moon \& Kim, 2001; Oh et al., 2009) were predictors of attitudes towards websites. The tolerance values for each of the independent variables exceeded the 0.10 cut-off level, and the average variance inflation factor (VIF) of 1.78 was well below the cut-off of 10 (Pallant, 2013). As such, there is no evidence of multicollinearity between the variables.

\section{Figure 2: Hypothesis testing results}

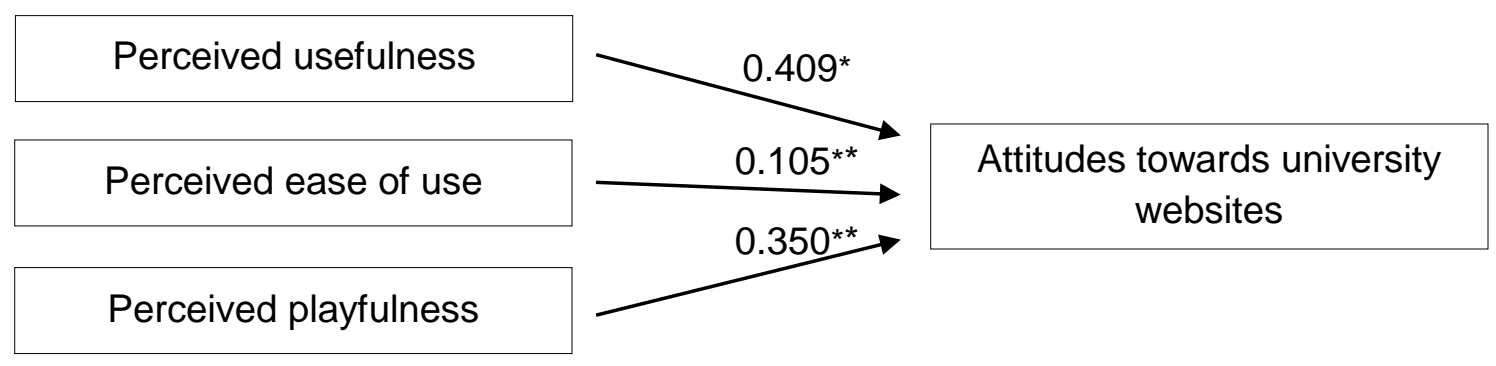

${ }^{*}$ Significant at the 0.05 level

Source:Own research

\section{LIMITATIONS AND FUTURE RESEARCH}

Notwithstanding the contribution made by this study, some limitations can be identified, which, in turn, present future research opportunities. Firstly, the sample used in this study was limited to students registered at HEls in the Gauteng Province of South Africa. As such, caution should be exercised in generalising the results to the wider Generation $Y$ population. A comparative study could be conducted across the other South African provinces or across various countries.Secondly, the aim of this study was to determine the factors that influence Generation $Y$ students' attitudes towards university websites and not to reveal the reasons for these influences. Therefore, the opportunity exists to conduct a qualitative research study in an attempt to gain a deeper understanding of Generation $Y$ students' attitudes towards university websites and the reasons for these influences.Lastly, given that the factors examined in this study only explained 57 percent of the variance in Generation Y students' attitudes towards their university website, there is an opportunity to investigate several other antecedents of attitudes towards university websites.

\section{DISCUSSION}

The purpose of this study was to determine the influence of usefulness, ease of use and playfulness on Generation $Y$ students' attitudes towards university websites within a South African context. The findings of the study suggest that Generation Y students have a positive attitude toward their university website and perceive their university website as being easy to use, playful and useful. Furthermore, the findings show that usefulness, ease of use and playfulness are positively correlated with attitudes towards university websites. The study also found that usefulness, ease of use and playfulness are positive 
predictors of attitudes towards university websites, with usefulnessbeing the strongest predictor of Generation Y students' attitudes toward university websites.

Given that the usefulness of university websites is the main contributor to Generation $Y$ students' attitudes towards these sites, it is essential that universities should carefully consider the content displayed on their websites. The main reason why users visit websites is to access information, and therefore, universities should ensure that they meet the user's requirements in terms of the information he or she is seeking. In order to achieve this, universities should determine what type of content the users require. By providing relevant content, the likelihood of the users revisiting the site increases. To capture and maintain the user's attention, the content on the website should be useful, unique and fresh, which requires regularly reviewing and updating the content. In addition, instead of overwhelming the user with too much information, rather capture the user's attention by making use of other media forms, such as videos. In terms of the perceived ease of use of university websites, users prefer a website that requires minimal mental and physical effort; that is, a website structure, interface, functions and content that areeasily understandable and quick to find.Although creative website layouts assist with differentiating the website from others, it is more important to ensure that the information on the website is organised in a logical manner and not cluttered together. To achieve this, universities should make use of headings, subheadings and bullet points instead of including large chunks of text. By making use of headings or phrases that are meaningful and make logical sense, users would be able to navigate the site easily and find the relevant information quickly. Considering the influence that the playfulness of a university website has on students' attitudes towards the site, universities should not only ensure that their website captures the attention of the users, but that italso instils curiosity among the users and provides an interesting and fun experience.In an effort to incorporate the fun element into the website, universities are encouraged to use images, illustrations or videos to convey information, rather than paragraphs. Videos can be particularly usefulto share activities or events that took place at the university, as it provides the user with the opportunity toget a glance at what those experiences are like. In addition, virtual tours are effective in showcasing the campus or particular areas of the university. In those cases where text is required to convey the information, it is recommended that universities should include a caption or small paragraph that is expandable. Furthermore, universities can incorporate a lucky draw competition on their website, whereby students complete a quiz that is based on the general information, latest news and achievements of the university, in order to be considered for the lucky draw.This will not only create excitement,butencourage students to browsethrough the information on the website. Universities could also link their social media accounts to their websites. By providing the links on the website, users are able to easily access and explore the university's social media pages.Although the playfulness of any website is 
important, caution should be taken, since too many playful elements could reduce the perceived reliability of the website.

\section{CONCLUSION}

University websites play a profound role in attracting potential students and keeping current students and stakeholders informed. Therefore, it is essential that universities should understand the factors that influence Generation $Y$ students' attitudes towards their websites. This study found that the ease of use, usefulness and playfulness of university websites have a significant positive influence on Generation Y students' attitudes towards university websites. Universities can use the insight gained from this study to improve the effectiveness of their websites in an attempt to positively influence Generation Y students' attitudes towards the sites.

\section{REFERENCES}

AHN, T., RYU, S. \& HAN, I. (2007). The impact of Web quality and playfulness on user acceptance of online retailing. Information \& Management, Vol. 44, pp. 263-275.

ALLEN, M. (2012). What was Web 2.0? Versions as the dominant mode of internet history. New Media \& Society, Vol. 15, No. 2, pp. 260-275.

ANCTIL, E.J. (2008). Selling higher education: marketing and advertising. ASHE Higher Education Report, Vol. 58, No. 3, pp. 357-376.

BILGIHAN, A. (2016). Gen Y customer loyalty in online shopping: An integrated model of trust, user experience and branding. Computers in Human Behavior, Vol. 61, pp. 103-113.

CARNEVALE, D. (2005). To size up colleges, students now shop online. http://resolver.ebscohost.com.nwulib.nwu.ac.za/openurl?sid=google\&auinit=D\&aulast=Carnevale\&ati tle=To+size+up+colleges\%2c+students+now+shop+online\&title=Chronicle+of+Higher+Education\&vo lume $=51$ \&issue $=40 \&$ date $=2005 \&$ spage $=A 25 \&$ site $=$ ftf-live. . Accessed 2018/06/16.

CASALO, L., FLAVIAN, C. \& GUINALIU, M. (2008). The role of perceived usability, reputation, satisfaction and consumer familiarity on the website loyalty formation process. Computers in Human Behavior, Vol. 24, pp 325-345.

CHEN, Q. \& WELLS, W.D. (1999). Attitude toward the site. Journal of Advertising Research, Vol. 39, No. 5, pp. 27-37.

CHUNG, J. \& TAN, F.B. (2004). Antecedents of playfulness: an exploratory study on user acceptance of general information-searching websites. Information \& Management, Vol. 41, pp. 869-881.

DAVIS, F.D. (1989). Perceived usefulness, perceived ease of use, and user acceptance of information technology. MIS Quarterly, Vol. 13, No. 3, pp. 319-340.

DEAN, G. (2010). Understanding consumer attitudes. https://marketography.com/2010/10/17/understanding-consumer-attitudes/. Accessed 2018/07/17.

DEPARTMENT OF HIGHER EDUCATION AND TRAINING see SOUTH AFRICA. DEPARTMENT OF HIGHER EDUCATION AND TRAINING.

FIELD, A. (2009). Discovering Statistics using SPSS. 3rd edition. London: Sage.

FLAVIAN, C., GUINALIU, M. \& GURREA, R. (2006). The role played by perceived usability, satisfaction and consumer trust on website loyalty. Information \& Management, Vol. 43, pp. 1-14.

GANIYU, A.A., MISHRA, A., ELIJAH, J. \& GANA, U.M. (2017). The Importance of Usability of a Website. The IUP Journal of Information Technology, Vol. 13, No. 3, pp. 27-35. 
GEFEN, D. (2003). TAM or just plain habit? A look at experienced online shoppers. Journal of End User Computing, Vol. 15, No. 3, pp. 1-13.

HAIR, J.F., BLACK, W.C., BABIN, B.J. \& ANDERSON, R.E. (2010). Multivariate data analysis: a global perspective. New Jersey: Pearson Prentice Hall.

HANNA, N. \& WOZNIAK, R. (2001). Consumer behaviour: an applied approach. New Jersey: Pearson Prentice Hall.

HIMANSU, S.M. (2009). Consumer behaviour -4: attitude individual determinants of behaviour. https://www.scribd.com/doc/19769789/Consumer-Behaviour-4-Attitude.Accessed: 2015/07/17.

HUNG, S., TSAI, J.C. \& CHOU, S. (2016). Decomposing perceived playfulness: a contextual examination of two social networking sites. Information \& Management, Vol. 53, pp. 698-716.

JOUBERT, P., ERDIS, C., BRIJBALL PARUMASUR, S. \& CANT, M.C. (2013). Introduction to consumer behaviour. 2nd ed. Cape Town: Juta.

LIAO, C., TO, P., LIU, C., KUO, P. \& CHUANG, S. (2011). Factors influencing the intended use of web portals. Online Information Review, Vol. 35, No. 2, pp. 237-254.

LIU, C. \& ARNETT, K. P. (2000). Exploring the factors associated with Web site success in the context of electronic commerce. Information \& management, Vol. 38, No. 1, pp. 23-33.

MARKERT, J. (2004). Demographics of age: generational and cohort confusion. Journal of Current Issues and Research in Advertising, Vol. 26, No. 2, pp. 11-25.

MENTES, S.A. \& TURAN, A.H. (2012). Assessing the usability of university websites: an empirical study on Namik Kemal University. The Turkish Online Journal of Educational Technology, Vol. 11, No. 3, pp. 61-69.

MOON, J. \& KIM, Y. (2001). Extending the TAM for a World-Wide-Web context. Information \& Management, Vol. 38, pp. 217-230.

NADEEM, W., ANDREINIB, D., SALOA, J. \& LAUKKANEN, T. (2015). Engaging consumers online through websites and social media: a gender study of Italian Generation $Y$ clothing consumers. International Journal of Information Management, Vol. 35, pp. 432-442.

OH, S.H., KIM, Y.M., LEE, C.W., SHIM, G.Y., PARK, M.S. \& JUNG, H.S. (2009). Consumer adoption pf virtual stores in Korea: focusing on the role of trust and playfulness. Psychology and Marketing, Vol. 26, No. 7, pp. 652-668.

PALLANT, J. (2016). SPSS survival manual: a step by step guide to data analysis using IBM SPSS. 6th ed. New York: McGraw-Hill.

SAICHAIE, K \& MORPHEW, C.C. (2014). What college and university websites reveal about the purposes of higher education. The Journal of Higher Education, Vol. 85, No. 4, pp. 499-530.

SCHIFFMAN, LG., KANUK, L.L. \& WISENBLIT, J. (2010). Consumer behaviour. Pearson Prentice Hall.

SCHNEIDER, G.P \& BRUTON, C.M. (2004). Communicating with multiple stakeholders: building effective university web sites.Journal of Organizational Culture, Communications and Conflict, Vol. 8, No. 2, pp. 73-80.

SCHNEIDER, G.P \& PERRY, J.T. (2000). Electronic commerce. Cambridge: Course Technology.

SEOCK, Y. \& NORTON, M. (2007). Attitude toward internet web sites, online information search, and channel choices for purchasing. Journal of Fashion Marketing and Management, Vol. 11, No. 4, pp. 571-586.

SERENKO, A. \& TUREL, O. (2007). Are MIS research instruments stable? An exploratory reconsideration of the computer playfulness scale. Information \& Management, Vol. 44, pp. 657-665.

SEVERT, K., FJELSTUL, J. \& BREITER, D. (2013). Information communication technologies: Usages and preferences of Generation $\mathrm{Y}$ students and meeting professionals. Journal of Convention \& Event Tourism, Vol. 14, No. 2, pp. 124-143. 
SINDHUJA, P.N \&DASTIDAR, S.G. (2009). Impact of the factors influencing website usability on user satisfaction. The IUP Journal of Management Research, Vol. 8, No. 12, pp. 54-66.

SOUTH AFRICA. DEPARTMENT OF HIGHER EDUCATION AND TRAINING. (2017). Statistics on postschool education and training in South 2015. http://www.dhet.gov.za/DHET\%20Statistics\%20Publication/Statistics\%20on\%20Post-

School\%20Education\%20and\%20Training\%20in\%20South\%20Africa\%202015.pdf. Accessed 2018/05/08.

SUN, H.M. \& CHENG, W.L. (2009). The input-interface of Webcam applied in 3D virtual reality systems. Computers \& Education, Vol. 53, No. 4, pp. 1231-1240.

VALENTINE, D.B. \& POWERS, T.L. (2013). Online product search and purchase behavior of Generation Y. Atlantic Marketing Journal, Vol. 2, No. 1, pp. 76-91.

VAN DER HEIJDEN, H. (2003). Factors influencing the usage of websites: the case of a generic portal in The Netherlands. Information \& Management, Vol. 40, pp. 541-549. 